\title{
Keterlibatan Guru PAK SMU Negeri Se-Kota Kupang dalam Pelayanan Gereja
}

\author{
Daud Saleh Luji; Indriani Lopo; Ana V. Soinbala \\ Institut Agama Kristen Negeri Kupang \\ Korepondensi: salehluji254@gmail.com
}

\begin{abstract}
Abstrak: Tujuan dari penulisan artikel ini adalah untuk mengetahui keterlibatan dan keaktifan Guru-guru PAK yang ada di Sekolah Menengah Umum (SMU) Negeri se-Kota Kupang dalam pelayanan bidang kemajelisan gereja sebagai presbiter dan sebagai pelayan kategorial khususnya kategorial anak dan remaja atau yang sering disebut sekolah minggu. Metode yang dipakai dalam penelitian ini adalah metode kualitatif dengan mewawancarai 41 Guru PAK yang tersebar di 12 SMU Negeri yang ada di wilayah Kota Kupang, Nusa Tenggara Timur. Dari hasil penelitian ditemukan bahwa walaupun Guru PAK ini memiliki pemahaman yang benar tentang latarbelakang kehadirannya di sekolah yaitu guru PAK adalah pelayan gereja yang diutus untuk melayani jemaat di sekolah-sekolah, namun sebagian besar guru PAK belum memiliki hubungan dengan gereja atau belum terlibat dalam pelayanan gereja, dimana ia sebagai anggotanya, baik sebagai presbiter maupun sebagai pelayan anak dan remaja (sekolah minggu). Kesimpulan tersebut dikemukakan berdasarkan pengakuan informan pada saat wawancara bahwa 1) Mereka tidak punya waktu luang untuk terlibat dalam pelayanan di gereja, 2) Pelayanan gereja sudah banyak orang yang mengurusnya karena itu mereka tidak perlu terlibat, 3) Guru PAK digaji oleh negara bukan gereja sehingga mereka lebih fokus mengurus pengajaran di sekolah dari pada di gereja.
\end{abstract}

Kata kunci: keterlibatan, guru PAK, pelayanan gereja

Abstract: The purpose of writing this article is to determine the involvement and activeness of Christian Religious Education Teachers at Public Middle Schools in Kupang City in the ministry of clerical affairs as presbyters and as categorical servants, especially in the category of children and adolescents or what is often called Sunday school. The method used in this study is a qualitative method by interviewing 41 Christian Religious Education Teachers spread across 12 State Public Middle Schools in the city of Kupang, East Nusa Tenggara. From the results of the study, it was found that although this Christian Religious Education teacher had a correct understanding of the background of his attendance at school, namely Christian Religious Education teachers were church servants sent to serve congregations in schools, but most Christian Religious Education teachers did not have a relationship with the church. or not yet involved in the church ministry where he is a member, either as a presbyter or as a minister of children and youth (Sunday school). This conclusion was stated based on the informant's admission during the interview that 1) They did not have free time to be involved in church services, 2) Church services had many people taking care of it so they did not need to be involved, 3) Christian religious education teachers were paid by the state, not church so that they focus more on taking care of teaching in schools than in church.

Keywords: involvement, Christian Religious Education teachers, church service 


\section{PENDAHULUAN}

Gereja hadir di muka bumi ini karena rencana dan kehendak Allah untuk melaksanakan tugas yang diberikan oleh Allah, dan menurut Howard Snyder yang dikutip oleh Sidjabat bahwa tugas Gereja adalah pertama, bersaksi dan menceritakan tentang perbuatanperbuatan Allah di dalam Yesus yang besar kepada seluruh umat manusia dan segala bangsa. Kedua, Gereja dipanggil untuk bersekutu, dan dalam persekutuan itu, adanya saling melayani di antara sesama manusia. ${ }^{1}$ Di samping itu Sidjabat juga menguraikan bahwa Yesus memberikan tugas kepada Gereja untuk menjadikan semua bangsa murid-Nya, dan tugas ini diwujudkan oleh Gereja dengan melaksanakan penginjilan, pembaptisan (peneguhan iman) dan pengajaran. ${ }^{2}$ Ketiga hal ini sama penting guna mewujudkan tugas pemuridan tersebut.

Menurut Oci, sebagai tubuh Kristus, yang terdiri dari persekutuan orang percaya dan juga institusi (lembaga), maka gereja harus mampu membawa umat untuk bertumbuh dalam iman kepada Allah melalui Yesus Kristus oleh firmanNya. Karena itu gereja harus mengajar dan membina umatnya sehingga dapat hidup berkualitas sesuai imannya. $^{3}$

Dari penjelasan di atas menunjukkan bahwa tugas pengajaran adalah salah satu tugas gereja yang sangat penting di samping tugas-tugas lain. Oleh karena itu Pengajaran gereja seharusnya dilaksanakan dan ditanggung sendiri oleh gereja, karena Pengajaran gereja merupakan amanat dari Yesus Kristus sendiri kepada Jemaat-Nya, sebagaimana digambarkan oleh Paulus dalam Efesus 4:11 bahwa Tuhan telah memanggil dan mengangkat dari antara anggota-anggota Gereja baik Rasul-rasul maupun Nabi-nabi, baik pemberita Injil ataupun Gembala-gembala dan Pengajar-pengajar. Dengan kata lain Pengajar adalah salah satu jabatan dalam gereja. Pengajar

${ }^{1}$ B.S Sidjabat, Strategi Pendidikan Kristen, Suatu Tinjauan Teologis-Filosofis (Yogyakarta: Yayasan Andi, 1999): 121-122.

${ }^{2}$ Ibid.

${ }^{3}$ Daniel Nuhamara, "Pengutamaan Dimensi Karakter dalam Pendidikan Agama Kristen," Jurnal Jaffray 16, no. 1 (2018): 93-114. yang dimaksud di sini adalah orang yang dipanggil oleh Tuhan untuk melakukan tugas pengajaran gereja.

Tamaweol mengutip pendapat Calvin bahwa dalam gereja ada empat jabatan yaitu jabatan pendeta, pengajar (doctor), penatua dan diaken. Jabatan pengajar adalah suatu jabatan yang diemban oleh mereka yang diberi tugas untuk mengajarkan ajaran sehat kepada jemaat selaku orang percaya, sehingga kemurnian injil tetap terjaga dan tidak dirusak oleh orang-orang yang tidak memiliki pengetahuan tentang ajaran yang benar. ${ }^{4}$ Pertanyaannya adalah siapa yang dapat disebut sebagai pengajar? Menurut de Jonge "jabatan pengajar sangat luas mencakup semua orang yang memberi diri dan terlibat dalam pengajaran iman di gereja, termasuk guru-guru di sekolah dan dosen-dosen teologi yang ada di lembaga pendidikan tinggi teologi. ${ }^{5}$ Dengan demikian pengajar adalah seseorang yang memiliki kompetensi di bidang pengajaran gereja dan diserahi tugas dan tanggung jawab atas nama gereja untuk mengajarkan pengajaran iman kepada warga gereja.

Pengajaran gereja yang selanjutnya disebut dengan Pendidikan Agama Kristen (PAK) adalah program Pendidikan dan pengajaran yang dilakukan oleh gereja dengan tujuan untuk mendewasakan warga gereja dalam iman kepada Kristus. ${ }^{6}$ Lebih jauh Nuhamara menjelaskan Pendidikan Agama Kristen (PAK) adalah suatu upaya yang sadar, sistematis, dan berkesinambungan untuk menumbuhkembangkan iman Kristiani dalam diri warga komunitas imannya atau jemaat dalam berbagai kategori usia (mulai dari bayi sampai dengan lanjut usia), yang diselenggarakan baik itu dalam konteks keluarga, komunitas iman, dan sekolah formal. ${ }^{?}$

Kedua pendapat di atas memberikan gambaran bahwa tujuan PAK bermuara pada

${ }^{4}$ Roy D. Tamaweol, "Jabatan Gerejawi Menurut Calvin dan Implikasinya bagi Organisasi dan Tata Gereja Di Masa Kini," Educatio Christi 1, no. 1 (2020): 17-24.

${ }^{5}$ Ibid.

${ }^{6}$ Desi Sianipar, "Peran Pendidikan Agama Kristen di Gereja dalam Meningkatkan Ketahanan Keluarga," Jurnal Shanan 4, no. 1 (2020): 73-92.

${ }^{7}$ Nuhamara, "Pengutamaan Dimensi Karakter dalam Pendidikan Agama Kristen.” Jurnal Jaffray 16, no. 1 (2018): 93-114 
peningkatan dan peneguhan iman untuk semua usia. Gereja dalam melaksanakan tugas PAK dilakukan dengan berbagai cara dan menggunakan berbagai wadah, dan salah satu wadah yang dipakai adalah menggunakan sekolah sebagai tempat untuk mengajarkan PAK. Mengapa sekolah? karena di sekolah ada banyak siswa yang merupakan warga jemaat. Untuk berjalannya PAK di Sekolah maka, Gereja membutuhkan Guru-guru PAK yang profesional. Oleh karena itu seorang Guru PAK sebelum melaksanakan tugas mengajar di Sekolah harus dipersiapkan terlebih dahulu oleh Gereja dalam satu jenjang Pendidikan Guru, khususnya dalam bidang PAK.

Sehubungan dengan hal di atas Harianto mengemukakan bahwa PAK di sekolah umum harus bersifat gerejawi. Walaupun pelajaranpelajarannya dilakukan dalam gedung sekolah, tetap ini adalah pengajaran gereja dan bukan pengajaran sekolah, sehingga para murid dan guru harus sadar bahwa PAK di sekolah berpangkal dan mengarah pada gereja. ${ }^{8}$

Pada dewasa ini guru PAK sebagai pelaksana tugas Gereja di Sekolah diangkat dan bekerja sesuai Surat Keputusan Pemerintah bukan Gereja. Hal ini sangat membantu gereja dalam hal pembiayaan. Namun di sisi lain merupakan satu hal yang perlu diperhatikan oleh Gereja, karena terkadang membuat Guru PAK lupa, bahwa ia ada di sekolah sebagai utusan gereja untuk melakukan tugas pengajaran gereja. Gereja tidak berkeberatan bahkan bersyukur untuk menerima sokongan dari negara dalam bentuk dana, tetapi Guru PAK yang dibiayai oleh pemerintah seharusnya merasa dirinya orang yang bekerja untuk Gereja walaupun gajinya dibayar oleh pemerintah.

Dari pikiran di atas, guru PAK mestinya tidak saja mempunyai hubungan dengan sekolah tetapi juga dengan Gereja. Hubungan dengan sekolah yaitu Guru PAK bertugas untuk merealisasikan nilai dan kebenaran firman Tuhan yang dimilikinya ke dalam pengajarannya kepada anak-anak agar mereka mengenal Allah, Yesus dan merasakan Roh Kudus di dalam

${ }^{8}$ Harianto G.P, Pendidikan Agama Kristen dalam Alkitab dan Dunia Pendidikan Masa Kini (Andi Yogyakarta, 2016): 134 kehidupan sehari-hari, serta bertanggung jawab kepada Tuhan serta Bangsa dan Negaranya. Hubungan dengan Gereja yaitu Guru PAK harus menyadari bahwa ia diutus untuk melaksanakan tugas Gereja karena itu ia selalu dan senantiasa terlibat dan mengaktifkan diri dalam pelayanan di Jemaat, baik dalam aspek kemajelisan, maupun aspek kategorial fungsional. ${ }^{9}$ Dengan demikian Guru PAK di Sekolah tidak boleh memisahkan diri dari Gereja, karena PAK di Sekolah dilaksanakan dalam rangka pelaksanaan tugas Gereja.

Ada sejumlah penelitian yang telah dilakukan tentang peran guru PAK untuk meningkatkan keaktifan dalam mengikuti pembelajaran baik di gereja maupun di sekolah. Namun kajiannya penelitian terdahulu tersebut hanya melihat peran dan keaktifan guru PAK secara terpisah yaitu jika yang diteliti adalah guru PAK di sekolah maka yang menjadi fokus penelitian adalah peran dalam tugas pengajaran di sekolah. Jika yang diteliti adalah guru PAK di sekolah minggu atau guru PAK di gereja maka fokus penelitiannya adalah keaktifan dan peran dalam tugas pengajaran di kelas sekolah minggu atau di gereja

Sebagai contoh, Montolalu meneliti tentang peran guru Kristen dalam meningkatkan keaktifan siswa kelas 1 SD pada pembelajaran online, yang hasilnya adalah menuntut guru untuk terus kreatif dan inavatif dalam memanfaatkan teknologi pembelajaran di sekolah. $^{10}$ Selain Montolalu, Taopan juga meneliti tentang peran guru Kristen sebagai fasilitator dalam pembelajaran daring untuk meningkatkan keaktifan belajar siswa, dan kesimpulan dari hasil penelitiannya adalah peran guru sebagai fasilitator dapat meningkatkan keaktifan siswa dan dapat mengembangkan potensi yang dimilikinya sebagai gambar Allah. ${ }^{11}$ Selain dua contoh

${ }^{9}$ E. G. Homrighausen \& I. H. Enklar, Pendidikan Agama Kristen, (Jakarta BPK Gunung Mulia, 2012):151158

${ }^{10} \mathrm{H}$. Montolalu, "Peran Guru Kristen dalam Meningkatkan Keaktifan Siswa Kelas 1 SD Pada Pembelajaran Online" (Universitas Pelita Harapan, 2020): 21.

${ }^{11}$ L. Y. Taopan, "Peran Guru Kristen sebagai Fasilitator dalam Pembelajaran Daring untuk 
penelitian di atas, ada juga penelitian yang dilakukan oleh Karo-Karo tentang hubungan guru sekolah minggu dengan keaktifan anak dalam ibadah sekolah minggu di GMI Siloam Binjai, yang kesimpulan hasil penelitiannya adalah ada hubungan yang signifikan antara keaktifan guru sekolah minggu dengan keaktifan anak dalam mengikuti pembelajaran sekolah minggu. ${ }^{12}$

Beberapa contoh penelitian di atas mengkaji peran guru PAK di sekolah dan di gereja. Yang berbeda dari penelitian ini dengan penelitian sebelumnya adalah penelitian ini ingin mencari tahu tentang guru PAK yang mengajar di sekolah dan di gaji oleh pemerintah, namun tetap memiliki hubungan dan aktif dalam pelayanan gereja, baik sebagai presbiter maupun sebagai pelayan anak dan remaja (sekolah minggu). Dasar pemikiran dari penelitian ini adalah sebagaimana yang dikemukakan Homrighausen dan Enklar bahwa salah satu kriteria agar seseorang layak diserahi tugas dan tanggung jawab sebagai guru PAK di sekolah adalah memiliki kesetiaan dan dedikasi yang tinggi kepada gereja. ${ }^{13}$ Menurut penulis, yang menjadi indikator kesetiaan dan dedikasi seorang guru PAK yang mengajar di sekolah terhadap gereja adalah ia mestinya terlibat dalam pelayanan gereja, baik sebagai presbiter maupun pelayanan anak dan remaja. Sebab, jika seorang guru PAK yang mengajar di sekolah dan tidak terlibat sama sekali dalam pelayanan gereja maka kesetiaan dan dedikasinya terhadap gereja sulit diukur.

Di Kota Kupang ada banyak guru PAK yang bekerja sebagai guru negeri (Pegawai Negeri Sipil) yang ditempatkan pada sekolah-sekolah negeri, untuk mengajarkan pengajaran gereja kepada anak didik, namun dalam pengamatan peneliti kelihatannya Guru-guru PAK tersebut lebih mementingkan hubungannya dengan Sekolah, dan mengabaikan relasi dengan gereja

Mengembangkan Keaktifan Belajar Siswa” (Jakarta: Universitas Pelita Harapan, 2020), 28.

${ }^{12}$ Selamat Karo-Karo, "Hubungan Guru Sekolah Minggu Dengan Keaktifan Anak dalam Ibadah Sekolah Minggu di GMI Siloam Binjai Tahun 2017," Jurnal Pendidikan Religius 1, No. 1 (2019): 18-21.

${ }^{13}$ Homrighausen \& Enklar, Pendidikan Agama Kristen, 151-157 sebagai lembaga yang mengutusnya untuk mengajarkan ajaran gereja di sekolah. Kondisi ini merupakan satu kepincangan dari fungsi Guru PAK. Untuk membuktikan secara ilmiah bagaimana keterlibatan Guru-guru PAK dalam pelayanan Gereja di Jemaatnya maka, penulis melakukan penelitian di bawah judul Guru PAK Sebagai Pelayan Gereja.

Bertolak dari latar belakang di atas maka ada dua hal yang menjadi persoalan pokok yang ingin diteliti yaitu 1) Bagaimana keterlibatan dan keaktifan Guru-guru PAK SMU Negeri se Kota Kupang dalam pelayanan bidang kemajelisan (presbiter) di gereja tempat dimana ia menjadi anggotanya. 2) Bagaimana keterlibatan dan keaktifan Guru-guru PAK SMU Negeri se-Kota Kupang dalam pelayanan kategorial anak dan remaja ataupun katekisasi di gereja tempat dimana ia menjadi anggotanya.

\section{METODE}

Metode yang digunakan dalam penelitian ini adalah metode penelitian kualitatif. Sebagaimana diungkapkan Moleong, ${ }^{14}$ bahwa penelitian kualitatif adalah penelitian yang bermaksud untuk memahami fenomena tentang apa yang dialami oleh subyek penelitian misalnya perilaku, persepsi, motivasi, tindakan dll. Metode penelitian ini dipilih karena penelitian ini bermaksud untuk memahami fenomena tentang apa yang dialami oleh subyek penelitian secara holistik, yaitu tentang keterlibatan dan keaktifan guru PAK dalam pelayanan gereja di mana ia menjadi anggota jemaat, dan kemudian didiskripsikan dalam bentuk kata-kata dan bahasa pada suatu konteks khusus yang alamiah. Untuk mendapatkan data tersebut peneliti memasuki dunia informan dan melakukan wawancara (interview) terus menerus dan mendalam (deep interview) dengan informan, sampai mendapat berbagai informasi sehubungan dengan keterlibatan guru-guru PAK pada SMU Negeri se-Kota Kupang dalam pelayanan gerejanya.

${ }^{14}$ J. L. Moleong, Metodologi Penelitian Kualitatif (Bandung: Rosda Karya, 2000), 2-6 
Tujuan yang ingin di capai dari penelitian ini adalah ingin mengetahui keterlibatan dan keaktifan guru-guru PAK SMU Negeri Se-Kota Kupang dalam pelayanan gerejawi baik sebagai presbiter maupun sebagai pengajar dalam pelayan anak dan remaja (PAR) ataupun katekisasi sebagai bukti kesetiaan dan dedikasi mereka terhadap gereja yang mengutus mereka untuk ada dan mengajar di sekolah.

Untuk mendapatkan informasi yang akurat tentang permasalahan di atas maka penulis melakukan observasi terhadap kegiatan guruguru PAK di jemaat tempat ia menjadi anggota. Selain itu melakukan wawancara dengan 41 orang Guru PAK pada SMU Negeri se-kota Kupang. Setelah informasi dikumpulkan maka, untuk mengecek kebenaran data tertentu yang diperoleh dari informan, penulis melakukan trianggulasi sumber dengan cara membandingkan hasil wawancara guru PAK di sekolah antara satu dengan yang lainnya. Selain itu, juga membandingkan data dengan sejumlah pendeta jemaat, yang mana guru PAK tersebut menjadi anggota jemaatnya. Data yang diperoleh dianalisis menurut model interaksi data kualitatif Miles dan Huberman ${ }^{15}$. Karena menggunakan model analisis data Miles dan Huberman maka tahapannya adalah sebagai berikut: Pertama, Reduksi Data. Dalam langkah ini peneliti melakukan penelaah terhadap semua data yang diperoleh dari berbagai sumber dengan berbagai metode pengumpulan data. Kemudian peneliti menyusun abstraksi yaitu berusaha membuat rangkuman yang inti, mengenai pertanyaan-pertanyaan pada setiap fokus penelitian yang perlu sehingga tetap berada di dalamnya. Dalam langkah reduksi data, peneliti dapat mengabaikan berbagai data informasi yang diyakini tidak berhubungan dengan tujuan penelitian, atau jika terjadi kemubaziran data maka peneliti dapat menganulirnya. Kedua, Display Data. Data dari reduksi dipaparkan, peneliti membuat uraian secara rinci atas hasil temuan penelitian, sehingga dapat dibaca dan dipahami. Display data merupakan proses penampilan data secara sederhana dalam bentuk

\footnotetext{
${ }^{15}$ Sugiyono, Metode Penelitian Kuantitatif Kualitatif dan REDD (Bandung: Alfabeta, 2010): 246-252
}

kata-kata, naratif, table, matrik dan grafik dengan maksud agar data yang telah dikumpulkan dan dikuasai oleh peneliti sebagai dasar untuk mengambil kesimpulan yang tepat. Ketiga, Kesimpulan dan Verifikasi. Sejak awal peneliti berusaha mencari makna dari data yang dikumpulkan. Untuk maksud tersebut, peneliti berusaha mencari pola, model, tema, persamaan dari data yang diperoleh melalui langkah-langkah yang dilakukan di atas, peneliti dapat menafsirkannya secara benar, dan menarik suatu simpulan atas hasil penelitian yang telah dikatakan

\section{PEMBAHASAN}

Dari 12 Sekolah Menengah Umum Negeri yang ada di Kota Kupang, terdapat 41 orang Guru PAK yang mengajar Mata pelajaran Pendidikan Agama Kristen dengan sebaran sebagai berikut:

Tabel 1. Penyebaran Guru PAK berdasarkan Sekolah

\begin{tabular}{|c|c|c|c|c|}
\hline \multirow[t]{2}{*}{$\mathrm{NO}$} & \multirow[t]{2}{*}{$\begin{array}{c}\text { NAMA } \\
\text { SEKOLAH }\end{array}$} & \multirow{2}{*}{$\begin{array}{l}\text { JMLH } \\
\text { GURU } \\
\text { PAK }\end{array}$} & \multicolumn{2}{|c|}{$\begin{array}{c}\text { STATUS } \\
\text { PEGAWAI }\end{array}$} \\
\hline & & & PNS & HR \\
\hline 1 & SMUN 1 Kpg & 3 & 3 & - \\
\hline 2 & SMUN 2 Kpg & 4 & 3 & 1 \\
\hline 3 & SMUN $3 \mathrm{Kpg}$ & 6 & 3 & 3 \\
\hline 4 & SMUN 4 Kpg & 3 & 3 & 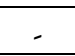 \\
\hline 5 & SMUN 5 Kpg & 4 & 3 & 1 \\
\hline 6 & SMUN 6 Kpg & 4 & 4 & 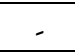 \\
\hline 7 & SMUN 7 Kpg & 4 & 2 & 2 \\
\hline 8 & SMUN 8 Kpg & 3 & 1 & 1 \\
\hline 9 & SMUN 9 Kpg & 2 & 2 & - \\
\hline 10 & SMUN $10 \mathrm{Kpg}$ & 3 & - & 3 \\
\hline 11 & SMUN $11 \mathrm{Kpg}$ & 2 & 1 & 1 \\
\hline 12 & SMUN $12 \mathrm{Kpg}$ & 3 & - & 3 \\
\hline & JUMLAH & 41 & 26 & 15 \\
\hline
\end{tabular}

Dari segi status kepegawaian, ada 26 orang atau $63,41 \%$ yang berstatus sebagai Pegawai Negeri Sipil (PNS) sedangkan ada 15 orang atau $36,58 \%$ sebagai guru tidak tetap atau guru honor. Sebagian guru PNS bekerja dengan gaji yang dibayar oleh pemerintah sesuai dengan peraturan penggajian negara, sedangkan mereka yang honorer dibayar dari dana Biaya 
Operasional Sekolah (BOS). Dalam penyebaran guru pun bervariasi, ada SMU Negeri yang memiliki jumlah guru PAK sampai 6 orang, karena jumlah siswa pada SMU tersebut sangat banyak seperti SMA Negeri 3 Kupang. Di sisi lain ada juga sekolah yang hanya memiliki 2 orang guru Agama karena jumlah siswanya sedikit. Namun dari data jumlah penyebaran Guru PAK yang ada menunjukkan bahwa semua siswa mendapat pengajaran dari guru PAK secara baik karena rata-rata seorang guru mengasuh 7 sampai 8 kelas per minggu.

\section{Pemahaman Guru PAK tentang Latar Belakang Penugasannya di Sekolah}

Sehubungan dengan pemahaman guru PAK akan latar belakang penugasannya di sekolah dan hubungannya dengan gereja tempat ia menjadi anggota maka, data menunjukan bahwa hanya ada 9,7\% yang merasa bahwa kehadirannya di sekolah bukan diutus gereja tetapi karena inisiatifnya sendiri. Di sisi lain ada sebagian besar atau $87 \%$ yang menyadari bahwa bahwa walaupun secara resmi gereja tidak mengutus mereka, namun karena tugas pengajaran yang diemban di sekolah adalah tugas gereja maka dengan sendirinya mereka adalah utusan gereja atau pelayan gereja. Hal ini sejalan dengan apa yang dikemukakan Campbell Wycoff $^{16}$ bahwa Gereja dalam melaksanakan tugas pengajarannya, ia membutuhkan wadah dan salah satunya adalah sekolah dan karena pengajaran yang dilaksanakan guru PAK di sekolah adalah pengajaran gereja maka yang melakukannya pun harus orang gereja. Lebih lanjut Homrighausen dan Enklaar ${ }^{17}$ mengatakan bahwa PAK di sekolah adalah tugas gereja, sehingga orang yang melakukan tugas tersebut harus orang gereja.

Dari pendapat di atas, maka dapat dikatakan bahwa Guru PAK yang mengajar di sekolah harus sadar bahwa karena PAK adalah ajaran gereja maka yang mengajar adalah warga gereja yang diserahi tugas dan tanggung jawab tersebut.

\footnotetext{
${ }^{16}$ Simanjuntak, Junihot M "Implikasi Konsep dan Desain Kurikulum dalam Tugas Pembinaan Warga Jemaat," Jurnal Jaffray 12, no. 2 (2014): 251-272.

${ }^{17}$ Homrighausen \& Enklar, Pendidikan Agama Kristen, 156-158
}

Guru PAK di sekolah pada masa sekarang ini, diberi upah oleh negara bukan oleh gereja, namun bukan berarti guru PAK tersebut menjauhkan diri dari pelayanan gereja. Guru PAK harus dan terus memiliki hubungan dengan gereja sebagai bukti pertanggungjawabannya dalam melaksanakan tugas gereja tersebut, karena sampai kapan pun guru PAK adalah utusan gereja untuk dan melayani pengajaran bagi jemaat lewat wadah sekolah. Sejalan dengan itu Ermindyawati mengatakan bahwa menjadi guru PAK adalah tugas mulia sehingga tidak boleh dianggap rendah oleh siapapun, karena pada dasarnya tugas ini adalah sangat penting dan sama dengan tugas pendeta dan gembala yaitu sebagai pelayan dalam gereja Tuhan yang harus dijunjung tinggi. ${ }^{18}$ Dengan kata lain Guru PAK adalah pelayan gereja yang diserahi tugas mulia karena itu guru PAK tidak boleh memisahkan diri dari gereja Tuhan.

\section{Keterlibatan Guru PAK dalam Pelayanan Gereja sebagai Presbiter, Pelayan Kategorial dan Fungsional}

Dalam hal keterlibatan guru PAK dalam pelayanan gereja di jemaat, baik sebagai pendeta, penatua, diaken, pengajar dan pelayan kategorial maka dapat paparkan sebagai berikut, bahwa dari 41 orang guru PAK yang ada di SMU Negeri se-Kota Kupang hanya ada 15 orang atau 36,58\% yang melibatkan diri sebagai presbiter, ada 5 orang atau $12,19 \%$ sebagai pengajar non presbiter, baik mengajar pada kelas katekisasi maupun pada kategori anak dan remaja, dan ada 3 orang atau $3,71 \%$ yang bukan presbitar tetapi memberi diri dalam pelayanan kategorial atau menjadi pengurus kategorial.

Ini berarti sebagian besar dari guru PAK tidak terlibat dalam pelayanan gereja. Walaupun dari segi pemahaman, sebagian besar memahami bahwa mereka adalah utusan gereja di sekolah, tetapi dalam prakteknya masih banyak yang belum terlibat dalam pelayanan gerejawi sebagai bukti bahwa mereka tetap memiliki hubungan dengan lembaga yang mengutusnya untuk

${ }^{18}$ Lilis Ermindyawati, "Peranan Guru Pendidikan Agama Kristen Terhadap Perilaku Siswa-Siswi," FIDEI: Jurnal Teologi Sistematika dan Praktika 2 (2019): 40-61. 
melayani di sekolah. Ketidakterlibatan mereka mengisyaratkan bahwa mereka seolah-olah memisahkan diri dari gereja yang mengutusnya. Kondisi ini akan berdampak negatif karena jika Guru PAK tidak terlibat atau tidak memiliki hubungan yang aktif dengan gereja maka lambat laun pengajaran yang dilakukannya hanya mengarah kepada kognitif semata, atau hanya menekankan aspek pengetahuan saja.

Menurut Tanduklangi ${ }^{19}$ PAK pada dasarnya bertujuan untuk menanamkan dalam diri anak yang belajar tentang nilai-nilai Kristiani agar ia bertumbuh mengenal Allah Tritunggal dan karya-Nya, terlebih melakukan apa yang dikehendaki oleh Allah dalam hidupnya. Ini berarti tujuan PAK bukan saja untuk mengetahui isi pengajarannya (kognitif), tetapi jauh lebih dari itu untuk melakukannya dalam kehidupan sehari-hari. Disini tuntutan bagi seorang guru PAK adalah sebelum Injil Yesus Kristus diajarkan kepada anak-anak, mestinya telah dilakukan terlebih dahulu oleh guru PAK. Menurut penulis jika guru PAK tidak terlibat dalam pelayanan gereja bagaimana mungkin mengajarkan tentang pelayanan gereja kepada anak-anak.

Selain keterlibatan guru PAK di jemaat sebagai presbiter, ada juga pelayanan lain yang dapat dilakukan oleh seorang guru PAK yaitu dengan terlibat dalam pelayanan kategorial dan fungsional, khususnya Pelayanan anak dan remaja, atau kategorial dan fungsional lainnya. Dari 41 orang guru PAK yang ada pada 12 SMU Negeri se-kota Kupang ditemukan bahwa, 15 orang atau $36,58 \%$ yang melibatkan diri sebagai presbiter. Ada 3 orang atau 7,32\% yang terlibat sebagai pengurus pelayanan anak dan remaja (Sekolah Minggu), dalam hal ini melibatkan diri sebagai pengajar PAR atau sekolah minggu dan pengajaran katekisasi.

Ini berarti sebagian besar tidak terlibat dalam pelayanan gereja. Walaupun guru PAK tidak terlibat sebagai presbiter tetapi mestinya Guru PAK harus terlibat dalam pelayanan kategorial khususnya pelayanan anak dan remaja ataupun

\footnotetext{
${ }^{19}$ Rinaldus Tanduklangi, "Analisis tentang Tujuan Pendidikan Agama Kristen (PAK) Dalam Matius 28: 19. 20," PEADA': Jurnal Pendidikan Kristen 1, no. 1 (2020): 47 58.
}

pelayanan katekisasi karena ia adalah orang yang profesional dalam bidang pengajaran gereja. Sebagaimana dikatakan Tindagi $^{20}$ bahwa ada sejumlah syarat yang harus dipenuhi oleh seorang guru PAK dan salah satunya adalah seorang guru PAK harus mempunyai pengetahuan yang cukup tentang isi iman Kristen. Ia harus mengenal Alkitab dengan baik. Untuk itu ia perlu dididik sebelum mengajar orang lain. Ini berarti Guru PAK telah melewati tahapan pendidikan khusus dan karena itu ia disebut sebagai orang yang memiliki kompetensi dibidang pengajaran PAK. Jika demikian maka harus ada hubungan timbal balik. Guru PAK diutus gereja untuk ada di sekolah tetapi sebagai seorang yang profesional di bidang PAK perlu membantu gerejanya dengan kompetensi yang dimiliki untuk mengembangkan pengajaran dalam gereja melalui pelayanan kategorial anak dan remaja ataupun katekisasi.

\section{Alasan Guru PAK Tidak Terlibat sebagai Presbiter, Pelayan Kategorial dan Fungsional}

Sehubungan dengan alasan ketidak-terlibatan guru PAK dalam pelayanan di gereja maka, hasil wawancara menunjukkan bahwa sebagian besar atau 53,65\% guru PAK yang tidak terlibat dalam pelayanan gereja sebagai presbiter karena berbagai alasan. Ada 3 orang atau 7,32\% mengatakan bahwa mereka tidak terpilih, ada 14 atau 34\% mengatakan bahwa mereka sangat sibuk dan tidak punya waktu untuk terlibat dalam pelayanan gereja sebagai presbiter. Ada 2 orang atau $4,87 \%$ yang mengatakan ia tidak terlibat karena bekerja di sekolah sudah cukup apalagi ia di gaji oleh negara bukan oleh gereja, dan ada 5 orang atau atau $12 \%$ yang mengatakan bahwa pelayanan gereja sudah ada yang urus.

Dari data di atas, ada beberapa yang mengemukakan alasan ketidakterlibatan mereka karena pelayanan gereja sudah ada yang urus sehingga tidak perlu dicampuri oleh guru PAK. Pendapat di atas terkesan bahwa pelayanan gereja sudah dibagi dalam masing-masing wadah, pengajaran di gereja, diurus oleh gereja

${ }^{20}$ Magdalena Grace K Tindagi, "Yesus: Sosok Guru Agung (Kompetensi Dan Profesionalitas Dasar Guru Pak)," Missio Ecclesiae 5, no. 1 (2016): 1-21. 
sedangkan pengajaran di sekolah diurus oleh Guru PAK di sekolah dan tidak perlu saling membantu. Padahal menurut penulis wadah memang berbeda tetapi tujuan pengajarannya sama, sehingga akan jauh lebih baik jika dua wadah ini saling berkontribusi oleh orang-orang yang ada di dalamnya.

Ada 2 orang yang sangat ekstrim dengan pikirannya bahwa ia bekerja sebagai guru PAK di sekolah dibayar oleh negara sehingga tidak perlu ada hubungan dengan gereja. Pendapat ini sangat keliru karena negara memang menghendaki agar setiap orang memeluk agamanya masing-masing, dan karena itu di sekolah perlu ada pengajaran agama untuk mempersiapkan warga negara ke depan yang sungguh-sungguh dalam iman dan bertaqwa kepada Tuhan, namun tidak berarti guru PAK terlepas dari gereja karena ajaran yang diajarkan adalah ajaran gereja, sehingga guru PAK harus selalu berhubungan dengan gereja, supaya terus diajar dan belajar tentang berbagai hal mengenai ajaran gereja. Menurut Calvin yang dikutip Tulung $^{21}$ bahwa salah satu golongan pelajar dalam gereja adalah para pengajar (guru) dan pendeta. Dengan kata lain guru agama harus terus belajar dari tempat yang mengutusnya untuk mengajar, sehingga ia terus dibimbing untuk bertumbuh dalam pengetahuan, pengenalan dan ketaatan yang sungguh kepada Kristus pemilik palayanan pengajaran gereja. Jika seorang guru memisahkan dari gereja dan tidak terlibat dalam pelayanan di gereja tempat ia menjadi anggota, maka ada kecenderungan guru PAK hanya mengajarkan ilmu pengetahuan tetapi tidak dapat membimbing anak-anak didik untuk memiliki hati yang setia kepada pelayanan gereja.

Seorang guru PAK yang baik, tidak saja mengajarkan sesuatu pengetahuan tentang iman kepercayaannya, tetapi lebih dari pada itu ia harus lebih dahulu mengalaminya. Sejalan dengan itu Homrighausen ${ }^{22}$ mengemukakan

\footnotetext{
${ }^{21}$ Jeane Marie Tulung dan Yornan Masinamboue, "Pemikiran Teologis Edukatif Yohanes Calvin serta Relevansinya bagi Pendidikan Bergereja Masa Kini," Tumou Tou (2020): 11-26.

${ }^{22}$ Homrighausen \& Enklar, Pendidikan Agama Kristen,165-168
}

salah satu tujuan PAK adalah bahwa agar anakanak, orang muda dan orang dewasa yang belajar PAK mengetahui tentang Gereja dan menjadi anggota Gereja yang setia, rajin dan bersekutu bersama-sama untuk membangun rumah Allah. Hal ini dapat terwujud apabila guru PAKnya sendiri menunjukkan keteladanannya kepada anak-anak. Telaumbanua ${ }^{23}$ juga mengatakan bahwa guru Pendidikan Agama Kristen yang profesional adalah guru yang tidak saja mampu melakukan Firman Tuhan di dalam kehidupannya, tetapi lebih dari itu menjadi teladan bagi jemaat yang diajarnya dan memberikan yang terbaik kepada jemaat melalui pelayanan dan pengajaran yang dilakukannya dengan sungguh-sungguh. Dengan kata lain keteladanan dalam melakukan firman Tuhan menjadi penting bagi anak-anak yang diasuhnya. Jika seorang guru PAK mengatakan bahwa orang Kristen harus selalu melayani Tuhan lewat gereja sedangkan ia sendiri menjauhkan diri dari pelayanan gereja maka akan menimbulkan kepincangan pengajaran karena hanya bersifat pengetahuan belaka

Sedangkan ada beberapa orang yang mengatakan bahwa mereka tidak terlibat dalam pelayanan sebagai presbiter, pelayanan kategorial dan fungsional karena tidak punya waktu atau alasan kesibukan. Menurut penulis alasan yang dikemukakan guru PAK tersebut menunjukkan bahwa guru PAK tersebut kurang memiliki rasa tanggung jawab terhadap gereja sebagai tempat yang mengutusnya untuk bekerja di sekolah. Menurut Homrighausen ${ }^{24}$ bahwa salah satu kriteria untuk menjadi guru PAK adalah memiliki kesetiaan dan dedikasi yang tinggi kepada Gereja. Dengan demikian jika guru PAK karena kesibukan lain dan tidak terlibat dalam pelayanan gereja maka sebetulnya ia belum memiliki kesetiaan dan dedikasi kepada gerejanya. Lebih khusus lagi pada kategorial anak dan remaja serta pengajaran katekisasi membutuhkan keterlibatan guru PAK. Mengapa

${ }^{23}$ Arozatulo Telaumbanua, "Profesionalisme Guru Agama Kristen Dalam Membina Jemaat,” ILLUMINATE: Jurnal Teologi dan Pendidikan Kristiani 3, no. 1 (2020): $12-$ 24. 
demikian? karena guru PAK adalah orang yang memahami ilmu pedagogik dan secara konten pengajaran dia adalah seorang yang profesional di bidangnya. Sehingga jika hal ini tidak dihiraukan oleh guru PAK dengan berbagai alasan, maka gereja akan mengalami krisis pengajaran, sebab para pendeta memiliki tugas pelayanan yang sangat banyak dalam jemaat.

\section{KESIMPULAN}

Guru PAK adalah orang profesional dalam bidang pengajaran gereja yang kepadanya diserahi tugas untuk mengajar jemaat. Pelaksanaan tugas ini dilaksanakan dalam berbagai wadah, salah satunya adalah sekolah. Satu hal yang penting untuk diketahui bahwa walaupun guru PAK diutus untuk melayani pengajaran gereja di sekolah namun guru PAK adalah pelayan gereja karena itu hubungan Guru PAK dengan gereja mestinya selalu terjalin secara baik.

Setelah dilakukan pembahasan tentang hubungan Guru PAK pada SMU Negeri se-Kota Kupang dengan gereja tempat ia menjadi anggota maka dapat disimpulkan hal-hal sebagai berikut: Pertama, sebagian besar guru PAK mengetahui dan memahami dengan benar bahwa ia hadir di sekolah sebagai utusan dan pelayan gereja, walaupun secara resmi gereja tidak mengutus mereka, namun karena tugas pengajaran yang diemban di sekolah adalah tugas gereja maka dengan sendirinya mereka adalah utusan gereja atau pelayan gereja. Kedua, ada sebagian besar dari guru PAK tidak terlibat dalam pelayanan gereja. Dari segi pemahaman, sebagian besar memahami bahwa mereka adalah utusan gereja di sekolah, tetapi dalam prakteknya masih banyak yang belum terlibat dalam pelayanan gerejawi. Ketiga, keterlibatan guru PAK di jemaat dalam pelayanan kategorial dan fungisonal lebih khusus untuk pelayanan anak dan remaja (Sekolah Minggu) sangat rendah. Padahal, yang sangat diharapkan adalah walaupun guru PAK tidak terlibat sebagai presbiter tetapi mestinya Guru PAK harus terlibat dalam pelayanan kategorial khususnya pelayanan anak dan remaja ataupun pelayanan katekisasi, karena kategori ini berhubungan dengan pengajaran, dan guru PAK adalah orang profesional dalam bidang pengajaran gereja. Keempat, ada beberapa alasan guru PAK tidak terlibat dalam pelayanan sebagai Presbiter maupun pelayan kategorial karena: a) Kesibukan atau tidak punya waktu luang setelah menjalankan tugasnya sebagai guru di sekolah. b) Ada juga yang tidak terlibat karena memiliki pemahaman bahwa pelayanan gereja sudah ada yang urus. c) Ada sebagian kecil yang beranggapan bahwa bekerja di sekolah sudah cukup karena ia di gaji oleh negara bukan oleh gereja. Dari tiga alaasan yang dikemukakan dapat ditarik kesimpulan bahwa guru PAK belum memahami tugas dan fungsinya secara baik, apalagi salah satu kriteria menjadi guru PAK adalah harus memiliki dedikasi yang tinggi kepada gerejanya.

Dari seluruh gambaran tentang keterlibatan guru PAK dengan gereja di atas maka pada akhirnya peneliti menyimpulkan bahwa guru PAK pada SMU Negeri se-Kota Kupang belum memiliki hubungan yang baik dengan gereja yang mengutusnya untuk ada di sekolah, untuk melaksanakan tugas pengajaran gereja.

Sesuai kesimpulan di atas peneliti dapat memberikan beberapa saran sebagai berikut: Pertama, Gereja perlu melakukan pembinaan secara rutin bagi guru PAK yang ada dalam jemaatnya, agar guru PAK selalu memiliki hubungan dengan gereja. Kedua, Gereja perlu memberikan kesempatan kepada guru PAK untuk mengambil bagian dalam pelayanan dalam jemaat. Ketiga, Guru PAK harusnya selalu menyadari bahwa kehadirannya di sekolah sebagai utusan gereja untuk melakukan pengajaran bagi warga gereja sehingga selalu mendekatkan diri dengan gereja yang mengutusnya. Keempat, Gereja secara lembaga baik jemaat, klasis maupun Sinode perlu mendata semua guru PAK yang ada dalam wilayah pelayanannya untuk terus di bimbing dan dilatih demi peningkatan kapasitas dan profesionalitasnya. 


\section{KEPUSTAKAAN}

Ermindyawati, Lilis. "Peranan Guru Pendidikan Agama Kristen Terhadap Perilaku SiswaSiswi." FIDEI: Jurnal Teologi Sistematika dan Praktika 2 (2019): 40-61.

G. P., Harianto. Pendidikan Agama Kristen Dalam Alkitab Dan Dunia Pendidikan Masa Kini. Andi Yogakarta, 2016.

Homrighausen, E. G \& I. H. Enklar. Pendidikan

Agama Kristen. Jakarta: BPK Gunung Mulia, 2012.

Karo-Karo, Selamat. "Hubungan Guru Sekolah

Minggu dengan Keaktifan Anak dalam Ibadah Sekolah Minggu Di GMI Siloam Binjai Tahun 2017." Jurnal Pendidikan Religius 1, no. 1 (2019): 18-21.

Moleong, J. L. Metodologi Penelitian Kualitatif. Bandung: Rosda Karya, 2000.

Montolalu, Hadassah. "Peran Guru Kristen

Dalam Meningkatkan Keaktifan Siswa

Kelas 1 SD Pada Pembelajaran Online."

Universitas Pelita Harapan, 2020.

Nuhamara, Daniel. "Pengutamaan Dimensi

Karakter Dalam Pendidikan Agama

Kristen.” Jurnal Jaffray 16, no. 1 (2018): 93-114.

Sianipar, Desi. "Peran Pendidikan Agama

Kristen Di Gereja Dalam Meningkatkan

Ketahanan Keluarga." Jurnal Shanan 4, no. 1 (2020): 73-92.

Sidjabat, B.S. Strategi Pendidikan Kristen, Suatu

Tinjauan Teologis-Filosofis. Yogyakarta: Yayasan Andi, 1999.

Simanjuntak, Junihot M. "Implikasi Konsep Dan Desain Kurikulum Dalam Tugas

Pembinaan Warga Jemaat.” Jurnal Jaffray 12, no. 2 (2014): 251-272.

Sugiyono. Metode Penelitian Kuantitatif Kualitatif Dan REDD. Bandung: Alfabeta, 2010.

Tamaweol, Roy D. "Jabatan Gerejawi Menurut Calvin Dan Implikasinya Bagi Organisasi Dan Tata Gereja Di Masa Kini." Educatio Christi 1, no. 1 (2020): 17-24.

Tanduklangi, Rinaldus. "Analisis Tentang Tujuan Pendidikan Agama Kristen (PAK) Dalam Matius 28: 19-20.” PEADA': Jurnal Pendidikan Kristen 1, no. 1 (2020): 47-58.
Taopan, Linda Yunita. "Peran Guru Kristen Sebagai Fasilitator Dalam Pembelajaran Daring Untuk Mengembangkan Keaktifan Belajar Siswa." Universitas Pelita Harapan, 2020.

Telaumbanua, Arozatulo. "Profesionalisme Guru Agama Kristen Dalam Membina Jemaat.” ILLUMINATE: Jurnal Teologi dan Pendidikan Kristiani 3, no. 1 (2020): 12-24.

Tindagi, Magdalena Grace K. "Yesus: Sosok Guru Agung (Kompetensi Dan Profesionalitas Dasar Guru Pak).” Missio Ecclesiae 5, no. 1 (2016): 1-21.

Tulung, Jeane Marie, and Yornan Masinamboue. "Pemikiran Teologis Edukatif Yohanes Calvin serta Relevansinya bagi Pendidikan Bergereja Masa Kini.” Tumou Tou (2020): $11-26$ 